\title{
Estudo de Material de Produção Escrita Realizado por Meio de Gêneros Textuais
}

Study of Writing Production Material through Textual Genres

Cleide Inês Wittke*

Resumo: Um grande número de pesquisas centradas no processo de ensino e aprendizagem de língua materna volta-se à análise de materiais didáticos. Mesmo que o material não seja garantia de um ensino de qualidade, ele pode ser visto como um primeiro passo a essa realização. A partir desse contexto e com base na abordagem interacionista sociodiscursiva, o presente artigo tem como objetivo analisar a constituição do material da Olimpiada de Lingua Portuguesa - Escrevendo o Futuro, mais especificamente as sequências que compõem a coleção Pontos de Vista, para investigar se as atividades e os exercícios nele propostos oferecem condições a um ensino produtivo de escrita, sob uma perspectiva discursiva, uma vez que o programa busca trabalhar com o texto, ou melhor, com o gênero textual. Após contextualizar histórica e teoricamente a proposta em estudo, segue-se analisando as sequências didáticas da referida coleção, a qual aborda o gênero artigo de opinião, na busca de elementos textuais, linguísticos, enunciativos e discursivos que definem e caracterizam esse projeto de escrita.

Palavras-chave: Produção escrita. Gêneros textuais. Interacionismo Sociodiscursivo.

Abstract: A great number of studies about the process of language teaching and learning have focused on the analyses of didactic materials. Even though

* Pós-doutora em Didática das Línguas pela Universidade de Genebra (2015); Doutora em Linguística Aplicada pela Pontífice Universidade Católica do Rio Grande do Sul (2006). Professora doutora adjunto IV - UFPEL. Contato: cleideinesw@yahoo.com.br. 
the didactic material itself does not guarantee successful learning, it can be seen as the first step towards this aim. Taken this into account and based on a socio-discursive interactionism approach to language, this article analyses the "Portuguese Language Olympics - Writing the Future"("Olímpiada de Língua Portuguesa - Escrevendo o Futuro”)pedagogic material, in particular the sequences that make up the "Points of View " ("Pontos de Vista") volume, in order to investigate whether its didactic activitiesand exercises are in line with good practices of writing production, especially considering that the pedagogic material claims to work with textual genres. After contextualizing historically and theoretically the material under study, the didactic sequences in which argumentative essays are dealt with are analyzed in order to look for textual, linguistic, discursive and enunciative elements that can define and characterize the writing project.

Keywords: Writing production. Textual genres. Socio-Discursive Interacionism.

\section{Introdução}

A linguagem é uma potencialidade de expressão bastante complexa que envolve muitos aspectos. Ela diz respeito a variadas operações tanto de caráter linguístico, textual, pragmático, enunciativo quanto discursivo, uma vez que se manifesta em diferentes níveis de comunicação, nas mais diversas situações enunciativas. Pensando então a linguagem enquanto processo de interação, que abrange atividades e ações sociais (MACHADO, 2005), vemos que ela está constantemente presente em nosso cotidiano, mesmo que nem sempre nos damos conta dessa realidade. A linguagem se manifesta em diversos campos discursivos, sob diferentes materialidades e modalidades, verbais e não verbais, como já dizia Bakhtin (1992), esse fenômeno ocorre nas mais diferentes esferas humanas, através de mensagens corporificadas em diversos gêneros textuais, segundo Marcuschi (2002), ou em gêneros de texto, conforme Bronckart (2012), Schneuwly e Dolz (2009, 2010).

Nessa vasta área de reflexão, que engloba a linguagem de modo geral, e o ensino de língua materna de modo particular, direcionamos nossa investigação a um foco ainda mais restrito: à análise de materiais didáticos 
produzidos para a realização desse ensino. Considerando também o grande número de material existente, julgamos pertinente centrar nosso estudo no projeto de escrita do governo federal intitulado Olimpiada de Lingua Portuguesa - Escrevendo o Futuro. Selecionamos esse material por tratar-se de uma proposta interessante e recente, que realizou poucas edições, portanto, foi pouco estudada e consiste em uma materialidade com informações ricas para estudos no campo textual, linguístico e discursivo.

A partir desse quadro, depois de contextualizar o tema em questão, seguimos nossa reflexão explicitando a origem e descrevendo o projeto de escrita da Olimpíada de Língua Portuguesa (LP), bem como o material que o constitui e a linha teórica que fundamenta a proposta. $\mathrm{Na}$ sequência, enfocamos o papel do gênero textual nesse programa e a importância do procedimento metodológico por meio de oficinas e sequências didáticas. Feito isso, direcionamos nosso estudo especificamente à proposta de escrita de um artigo de opinião, voltada ao $2^{\circ}$ e $3^{\circ}$ anos do Ensino Médio (EM). Para tanto, descrevemos e analisamos cada uma das 31 etapas que constituem as 15 oficinas propostas, bem como sua coletânea de textos. Para finalizar, apresentamos nossas considerações sobre o material em foco e sua possibilidade de aperfeiçoar a capacidade de escrita do aluno, nas aulas de língua materna.

\section{Contextualização Histórica e Descrição do Material Didático Voltado à Prática da Escrita}

O projeto nacional de Olimpíada de Lingua Portuguesa - Escrevendo o Futuro diz respeito a um programa de formação de professores, organizado pela Fundação Itaú Social (FIS) e pelo Ministério da Educação (MEC), com apoio técnico do Centro de Estudos e Pesquisas em Educação, Cultura e Ação Comunitária (CENPEC), com vistas a proporcionar ensino de qualidade a todos os estudantes das escolas públicas brasileiras. A equipe organizadora dessa proposta de escrita explica tratar-se de um trabalho contínuo e de caráter bienal com vistas a proporcionar aperfeiçoamento tanto na formação continuada dos professores da rede pública como na capacidade dos alunos de se expressarem por escrito, nos diferentes gêneros textuais que circulam em nosso meio social. Conforme esclarece o documento 
(na seção denominada Caro Professor), nos anos ímpares, a proposta se volta a agentes educacionais (técnicos de secretarias de educação, diretores, professores). Já nos anos pares, "promove um concurso de produção de texto para alunos do $5^{\circ}$ ano do Ensino Fundamental ao $3^{\circ}$ ano do Ensino Médio" (OLIMPÍADA DE LP, 2010, p. 3).

A primeira versão do programa, iniciado em 2002, destinava-se apenas a alunos de $4^{a}$ e $5^{a}$ séries do Ensino Fundamental $(\mathrm{EF})$ e, já com o tema $O$ lugar onde vivo, englobava três gêneros textuais: Reportagem, Texto de Opinião e Poesia. No ano de 2003 (ímpar), dedicado à formação de professores, apresentou um Kit Vozes, publicando Voz do aluno, Voz do professor e um vídeo Escrevendo na sala de aula. Esse material foi distribuído nas escolas como forma de apoio pedagógico. A mudança em 2004 foi a troca do gênero Reportagem pelo de Memórias Literárias e, em 2005, foram criadas duas novas atividades de apoio pedagógico: a revista $\mathrm{Na}$ ponta do lápis, distribuída aos professores participantes da Olimpíada de LP e a comunidade virtual Escrevendo o futuro, espaço para diálogo interativo entre os participantes da atividade de escrita. Já em 2006, o Programa passou a premiar também os professores, sob a modalidade de Relato de Prática.

Seguindo sua trajetória, em 2008, o Ministério da Educação assumiu parceria nesse Projeto, possibilitando que todas as séries (anos) finais do Ensino Fundamental e também do Ensino Médio pudessem participar da Competição, a qual passou a ser denominada de Olimpiadas de Lingua Portuguesa - Escrevendo o Futuro. Em 2009, houve duas novidades: a Maleta do Formador, contendo material para realizar reuniões pedagógicas, e o Jogo Q.P. Brasil, voltado ao desenvolvimento da capacidade argumentativa do aluno do EM. Em 2010, ocorreu a $2^{a}$ edição da Olimpíada de LP, material aqui em estudo e que foi enviado às escolas públicas brasileiras, com alunos do $5^{\circ}$ ao $9^{\circ}$ ano do EF e do $1^{\circ}$ ao $3^{\circ}$ ano do EM, abrangendo quatro gêneros: Poemas, Memórias Literárias, Crônicas e Artigos de Opinião.

Em 2011, a formação docente contou com três ações coletivas: 1) o Seminário $A$ escrita sob foco: uma reflexão em várias vozes (voltado a professores, técnicos de secretarias e especialistas de universidades); 2) o Curso Virtual Sequência Didática: aprendendo por meio de resenhas (ofertado a professores e técnicos do Brasil); e 3) o Curso Presencial Caminhos para o ensino da escrita, com encontros presenciais realizados em 27 Universidades brasileiras. Em 
2012 e em 2014, foram realizadas a $3^{a}$ e a $4^{a}$ edições da Olimpíada de LP, seguindo os mesmos moldes da anterior, mas, como não tivemos acesso a essa Coleção (e considerando que a proposta de escrita é bastante similar, uma vez que foram poucas as alterações), acreditamos não haver problemas em analisar o material publicado em 2010.

Mantendo o tema inicial, ou seja, - O lugar onde vivo -, a $2^{\text {a }}$ edição, publicada em 2010, exigiu que o aluno pesquisasse, investigasse e estudasse o entorno onde mora, buscando assuntos pertinentes para participar dessa proposta nacional, na medida em que ia aperfeiçoando sua capacidade de expressão, seja lendo, falando, mas principalmente escrevendo. Na ocasião, o aluno podia se inscrever em quatro categorias, dependendo de sua escolaridade, a saber: Poemas (Poetas da escola) - para $5^{\circ}$ e $6^{\circ}$ anos do EF; Memórias literárias (Se bem me lembro...) - para $7^{\circ}$ e $8^{\circ}$ anos do EF; Crônica (A ocasião faz o escritor) - para $9^{\circ}$ ano do EF e $1^{\circ}$ ano do EM; e Artigo de opinião (Pontos de vista) - para $2^{\circ}$ e $3^{\circ}$ anos do EM, material aqui em estudo.

Cabe destacar que cada uma dessas categorias (coleções) possui um kit, composto pelo Caderno do Professor (com orientações para a produção de textos), dez cadernos impressos com exemplos do gênero textual em estudo nas oficinas e um CD-ROM (com textos da coletânea e também com outros exemplares do mesmo gênero em duas versões: sonora e gráfica). No Caderno do Professor, encontramos diversas oficinas, organizadas em sequências didáticas, com atividades voltadas ao desenvolvimento da capacidade de se comunicar, principalmente, por escrito, via produção de gêneros textuais.

\section{Embasamento Teórico que Fundamenta a Proposta de Escrita Via Sequências Didáticas}

No que tange à constituição do Caderno do Professor, na seção intitulada Apresentação, encontramos a fala do Professor Dr. Joaquim Dolz fazendo uma apreciação do projeto Olimpiada de Lingua Portuguesa - Escrevendo o Futuro. E nos questionamos por que, dentre tantos estudiosos que investigam o processo de escrita, esse didaticista foi selecionado para se posicionar sobre essa atividade de escrita. A escolha se justifica pela importância desse autor espanhol que, atualmente, é professor na Unidade de Didática das Línguas 
na Faculdade de Psicologia e Ciências da Educação, na Universidade de Genebra, na Suíça, fazendo parte do grupo de pesquisa Grupo de Pesquisa para a Análise do Francês Ensinado (GRAFE), cujos trabalhos são voltados a estudos da didática de francês como língua materna. Além disso, o grupo realiza pesquisas voltadas à atuação do professor em sala de aula, com foco na produção do texto argumentativo e da oração relativa, trabalhos que deram origem ao livro "Des Objets Enseignés en Classe de Français", publicado em 2009.

Em parceria com outros estudiosos da linguagem, como é o caso de Jean-Paul Bronckart, Bernard Schneuwly, Michèle Noverraz, Jean-François de Pietro, dentre outros, Dolz vem, desde o ano de 1990, investigando, pesquisando e analisando questões referentes à didática das línguas e à formação de professores, com ênfase na elaboração de planos de ensino, na análise de material didático e na atuação do professor. Nesse contexto, destacamos o trabalho com os gêneros textuais, tanto orais como escritos e suas pesquisas e trabalhos, via sequências didáticas, voltadas notadamente à formação docente e à transposição didática (SCHNEUWLY; DOLZ, 2010).

No entender de Dolz (OLIMPÍADAS DE LP, 2010, p. 9), a proposta de escrita coletiva brasileira tende a contribuir com o desenvolvimento da aprendizagem da língua materna, na medida em que busca aperfeiçoar a prática do ensino de leitura e de escrita, fornecendo subsídios e ferramentas aos professores, apresentando sequências didáticas a serem desenvolvidas nos diferentes níveis de ensino. Trata-se, nas palavras do didaticista, de um programa "para o enfrentamento do fracasso escolar decorrente das dificuldades do ensino de leitura e de escrita no Brasil" (p. 9), na tentativa de reduzir o iletrismo.

Nesse sentido, Dolz defende a tese de que ler e escrever são competências a serem priorizadas na prática escolar e que o aluno deve aprender a ler com o manuseio dos mais diversos tipos de textos que circulam em nossa sociedade. Para o autor, "compreender e produzir textos são atividades humanas que implicam dimensões sociais, culturais e psicológicas e mobilizam todos os tipos de capacidade de linguagem" (OLIMPÍADAS DE LP, 2010, p. 10). Isso tanto nos pontos de vista social, cognitivo, afetivo como na capacidade do uso verbal. O autor complementa seu pensamento, lembrando que, se o professor almeja que o aluno identifique as regularidades 
de determinado gênero textual, é necessário que lhe sejam oferecidas ferramentas que o tornem capaz de analisar os textos pertencentes a esse gênero, conscientizando-o da situação de produção, bem como das diversas marcas linguístico-discursivas próprias desses textos, habilitando o estudante a fazerem uso dos gêneros de texto.

Para Dolz et al. (2011), escrever é um desafio a todos os cidadãos e a melhor condição para desenvolver essa competência consiste em aprendê-la praticando, ou seja, escrevendo com bastante frequência, os mais variados gêneros sociais existentes. Na sua fala, na Olimpíada de LP (2010, p. 11), Dolz defende que

Não é suficiente aprender o código e a leitura para aprender a escrever. Escrever se aprende pondo em prática a escrita, escrevendo-se em todas as situações possíveis: correspondência escolar, construção de livros de conto, de relatos de aventuras ou de intriga, convite para uma festa, troca de receitas, concurso de poesia, jogos de correspondência administrativa, textos jornalísticos (notícias, editorial, carta ao diretor de um jornal) etc.

Ao se referir à proposta da Olimpíada, o estudioso da linguagem ressalta a importância do papel do professor nesse processo de escrita, pois é ele quem apresenta a situação de comunicação e formula as instruções de produção explicando com clareza cada etapa das atividades, até que se chegue ao texto final (DOLZ et al., 2011). O importante é que a prática da proposta da Olimpíada de LP transcenda o propósito inicial (a competição) e desperte no docente (e também no educando) o desejo de continuar trabalhando com os gêneros textuais, aperfeiçoando e adaptando as sequências didáticas propostas no e pelo programa nacional, mudando, aos poucos, a metodologia de ensino de língua na rede educacional brasileira.

Dolz (2010) avalia como medida positiva a decisão dos organizadores da Olimpíada de LP em conceber a sequência didática como eixo norteador do ensino da escrita e aproveita para dar cinco conselhos aos professores brasileiros engajados nessa atividade de escrita. Orienta que o professor:

a) Inicie suas atividades propondo que o aluno produza um texto inicial, a partir do qual poderá diagnosticar aquilo que o educando 
já sabe e, também, sobre as informações que ainda desconhece do gênero em estudo;

b) Escolha e adapte as atividades propostas em conformidade com a realidade escolar e com as necessidades da turma, uma vez que a sequência didática serve de referência, mas pode e deve ser ajustada ao contexto em que será trabalhada;

c) Trabalhe com diversos textos do mesmo gênero textual, de fontes variadas, propondo leitura e comparação, pois essa prática dará subsídio para que o aluno conheça e use socialmente esse gênero;

d) Trabalhe sistematicamente as dimensões verbais, explorando as formas de expressão do português brasileiro;

e) Aos poucos, estimule e incentive a autonomia do aluno na escrita criativa.

No que tange ao Programa de Olimpíada de LP e do seu material, de modo especial, em entrevista concedida à autora deste artigo, o pesquisador Joaquim Dolz (2015) diz considerar que

... tudo o que o país faz, como é o caso da campanha para o desenvolvimento da leitura e da escrita, é fundamental. Eu sou particularmente partidário ao projeto da Olimpíada da língua portuguesa porque é um programa que trabalha sobre a escrita para o desenvolvimento da leitura. A escrita mobiliza sempre a leitura. Além disso, os organizadores distribuem materiais que creio sejam de qualidade para o trabalho escolar, mas também a ação da Olimpíada de LP tem um efeito na sociedade e não sei se você sabe que o Banco patrocinador distribui também contos, bem como propõe programas para apoiar e aconselhar os pais, e incentiva a presença de livros e a presença da escrita na família para o desenvolvimento cultural, através do letramento.

$\mathrm{Na}$ sequência da entrevista, ainda falando sobre o material da Olimpíada, o autor complementa:

A prova é que na Olimpíada de LP, as sequências que os organizadores elaboraram também são muito bem acolhidas pelos professores. E se 
faço um salto no Brasil, eu acho que os materiais escolares são de extrema importância e que o desenvolvimento de materiais escolares sobre os aspectos que nós discutimos é muito importante. Se a Olimpíada de LP deu bons resultados é porque eles elaboraram materiais que são muito bem acolhidos pelas escolas e também a distribuição do material está ligada a um trabalho de motivação com concursos literários para os alunos, mas, sobretudo, a uma formação dos professores.

Até a página 15, o material das quatro coleções é o mesmo; somente a partir dessa fase, com a rubrica Introdução ao gênero, cada coleção continua abordando um gênero específico, a saber: poemas/poesias; histórias com memórias literárias; crônicas; e artigos de opinião. Cada gênero é definido, comparado para ser caracterizado e, por fim, é produzido por escrito, após passar por etapas de reescrita coletiva e individual, com base em roteiros avaliativos norteadores.

\section{A Noção de Gênero Textual na Proposta de Escrita da Olimpíada de LP}

Ao ler e estudar as propostas que constituem as quatro coleções constituintes da Olimpíada Nacional de LP, é possível perceber que todo o programa está organizado sob uma perspectiva teórica que concebe o ensino de língua como um processo de interação verbal e tem o gênero textual como objeto de ensino da escrita. Cada atividade de produção de texto é feita a partir de oficinas com sequências didáticas focadas em um determinado gênero, de diferentes campos discursivos (MARCUSCHI, 2008), sejam eles literários ou midiáticos.

Nesse contexto, e pensando no professor de língua materna como um interlocutor, um mediador tanto das coleções como desta reflexão acadêmica, percebemos a importância de contextualizar teoricamente o programa em análise. Iniciamos nossa concepção com base na clássica definição de Bakhtin (1992), autor que define gênero como tipos de enunciados relativamente estáveis, na medida em que concebe o enunciado como "elo na cadeia da comunicação verbal" (p. 318), diferentemente da palavra e da oração, vistas pelo estudioso como unidade da língua (p. 315). 
Sob uma abordagem interacionista sociodiscursiva, podemos dizer que o gênero textual (de texto) refere-se às diferentes materialidades discursivas que o texto assume para desempenhar as mais diversas funções sociais, ressaltando suas propriedades sociocomunicativas de funcionalidade e de intencionalidade. Para Marcuschi (2002), são artefatos culturais historicamente construídos e usados pelo homem. Eles apresentam diferentes caracterizações, com vocabulários específicos e empregos sintáticos apropriados, em conformidade com o papel social que exercem. Isso justifica a importância do projeto da Olimpíada de LP, pois cria possibilidades para que o aluno estude (lendo, desconstruindo, analisando e reconstruindo) variados gêneros, considerando sua estrutura e circularidade, o que o torna capaz não só de reconhecê-los e compreendê-los, mas também de construí-los de modo adequado a funcionar em suas respectivas instâncias sociais.

Segundo Schneuwly (2010, p. 116), com base nos estudos de Bakhtin, "cada esfera comunicativa corresponde ao desenvolvimento de gêneros relativamente estáveis", portanto, os textos produzidos e distribuídos em cada comunidade linguística são reconhecidos sob tais características, na medida em que regulam boa parte do comportamento da linguagem. Em síntese, o autor complementa que um gênero constitui sua identidade sob três dimensões: "o que é dizível por meio dele (o conteúdo temático), a forma de organização do dito (a estrutura composicional) e os meios linguísticos que operam para dizê-lo (o estilo)".

Seguindo essa perspectiva, Brait (2002) enfatiza que, ao trabalhar com os gêneros, é fundamental que o professor leve em conta os aspectos que dizem respeito a seu processo de produção, circulação e recepção. Suas condições de produção e de recepção remetem à questão de quem produz a mensagem para quem; trata-se da identidade social do produtor e do receptor da mensagem. Já a circulação refere-se ao veículo ou suporte em que circula o dizer. Tais elementos discursivos são importantes à mensagem como um todo, pois explicam porque aquilo é dito daquela maneira e não de tantos outros modos possíveis. Ainda no que tange às condições de produção, vale enfatizar que todo texto é determinado em conformidade com a interação comunicativa estabelecida entre o produtor/autor e o receptor/interlocutor, o que pressupõe regras, valores e normas de conduta, advindas dos papéis sociais que os sujeitos desempenham na sociedade, o que atribui autoridade e legitimidade, ou não, a seu dizer. 
Tendo como base o princípio didático de que o gênero textual é uma questão de uso e a tipologia textual de forma e estrutura, quando nos referimos à segunda modalidade, reportamo-nos à denominação clássica que, por muito tempo, dominou essa nomenclatura, ou seja: descrição, narração e dissertação. Todavia, abordagens teóricas mais recentes ${ }^{1}$ flexibilizaram essa concepção ao dividir o texto dissertativo em expositivo ou argumentativo, dependendo da intenção do autor ao produzir sua mensagem, além de criar duas novas tipologias textuais: conversação e injunção.

Sob essas condições, na medida em que tais modalidades textuais passaram a circular em nossa sociedade, em diferentes situações de uso, exercendo função sociocomunicativa, e foram reconhecidas sob o papel de gêneros textuais, ampliando seu círculo de atuação, os homens foram criando mais e mais exemplares de gêneros, ao ponto de eles serem considerados praticamente inumeráveis. Felizmente, várias iniciativas didáticas, e também metodológicas, principalmente por meio de materiais didáticos, estão levando em conta o importante papel que o gênero textual desempenha em nossa vida social e os vêm incluindo nas atividades de ensino de língua, nas aulas de português. Exemplo concreto disso é o próprio projeto da Olimpiada de Lingua Portuguesa, material aqui em estudo, que foi organizado por meio de oficinas desenvolvidas através de sequências didáticas. E, segundo Schneuwly (2010), é importante que os professores privilegiem a entrada dos gêneros textuais no ensino de língua, porque esses megainstrumentos

... correspondem perfeitamente às exigências definidas por nossa concepção (de interação social) do desenvolvimento: são, a um só tempo, complexos e heterogêneos (mas fundados de certa maneira sobre uma heterogeneidade 'integrada'), produtos sócio-históricos, definíveis empiricamente, além de serem instrumentos semióticos para a ação de linguagem. (SCHNEUWLY, 2010, p. 115).

${ }^{1}$ Dentre os trabalhos dessa natureza, citamos Dolz, Rosat e Schneuwly (1991); Schneuwly (1994); Pereira et al. (2006); Guimarães et al. (2007); Bronckart (2008, 2012); Marcuschi (2002, 2008), Schneuwly e Dolz (2009, 2010). 


\section{Procedimento Metodológico por Meio de Oficinas e de Sequências Didáticas}

Como já comentado anteriormente, as quatro coleções que compõem o projeto de Olimpíadas de LP são organizadas por meio de oficinas, as quais, por sua vez, são divididas em diferentes etapas, chamadas por Schneuwly e Dolz (2010) de sequências didáticas. Para esses autores, a sequência didática consiste em um "conjunto de atividades escolares organizadas, de maneira sistemática, em torno de um gênero textual oral ou escrito" (p. 82). E ela tem o objetivo de auxiliar o aluno a melhor dominar o uso de um gênero textual, o que lhe possibilita falar ou escrever de modo mais adequado em determinada situação de comunicação (ver WITTKKE, 2007, 2015).

Conforme o esquema de sequência didática proposto por Dolz, Noverraz e Schneuwly, o qual pode ser conferido na obra Gêneros orais e escritos na escola (2010, p. 81-108), o ensino de língua, com base nos gêneros de texto, deve apresentar o seguinte procedimento: apresentação da situação, produção inicial - módulo 1 , módulo 2 , módulo 3 , módulo n - e produção final. Nessa perspectiva teórica, a sequência didática efetua um movimento que vai do mais complexo ao mais simples, ou seja, parte da produção inicial e segue em direção aos módulos, sendo que cada um deles desenvolve "uma ou outra capacidade necessária ao domínio de um gênero. No fim, o movimento leva novamente ao complexo: a produção final" (DOLZ; NOVERRAZ; SCHNEUWLY, 2010, p. 88).

Ainda no que se refere ao caráter modular da proposta de ensino e aprendizagem de língua materna, via gêneros orais e escritos, seus autores explicitam que ela precisa ser associada à diferenciação pedagógica, pois a heterogeneidade dos alunos e de suas capacidades de aprendizagem deve ser levada em conta na sistematização das atividades propostas. É nesse sentido que Dolz, Noverraz e Schneuwly (2010, p. 93-94) defendem que

... as seqüências didáticas apresentam uma grande variedade de atividades que devem ser selecionadas, adaptadas e transformadas em função das necessidades dos alunos, dos momentos escolhidos para o trabalho, da história didática do grupo e da complementaridade em relação a outras situações de aprendizagem da expressão, propostas 
fora do contexto das seqüências didáticas. É a partir de uma análise minuciosa da produção inicial que o professor poderá adaptar a seqüência didática à sua turma, a certos grupos de alunos de sua turma, ou ainda, a certos alunos.

Essa citação sustenta a tomada de posição de que é fundamental que o professor proponha diversas atividades com o objetivo de observar, comparar, identificar e analisar tanto elementos linguísticos, textuais como discursivos, no intuito de dominar o uso dos gêneros nas mais diversas situações de comunicação. Cabe lembrar que cada gênero de texto (com a intenção de narrar, relatar, argumentar, expor ou descrever ações) exige um ensino adequado à sua natureza, pois não há garantia de que um aluno que domina o processo de escrita de um texto narrativo, por exemplo, também terá o mesmo domínio ao escrever um texto argumentativo. Isso porque cada tipo de texto apresenta características distintas, as quais precisam ser trabalhadas no decorrer dos ensinos fundamental e médio, como propõe o projeto da Olimpíada de LP, abordando diferentes gêneros, em cada nível de escolaridade. Chegamos, então, ao estudo específico das sequências didáticas voltadas à produção escrita do gênero artigo de opinião.

\section{Investigação da Proposta de Escrita do Artigo de Opinião}

Nesta etapa de nossa reflexão, chegamos à seção do Caderno do Professor que aborda especificamente sobre o gênero textual em questão, ou seja, acerca do artigo de opinião e suas particularidades. Com a rubrica Introdução ao gênero, a proposta é desenvolvida sob a perspectiva de que somos seres sociais e o exercício da escrita está diretamente relacionado com a prática da cidadania. Segundo os próprios organizadores da Olimpíada, um dos principais objetivos da proposta é

... motivar alunos e professores a (re)conhecer questões polêmicas que atravessam nosso cotidiano. Afinal, entender o que está em jogo em cada caso, perceber 'quem é quem', certificar-se de interesses em disputas, estratégias em ação etc. são formas eficazes de se envolver nas questões que movem a vida em sociedade. Debatê-las, colaborando 
para a formação coletiva de respostas, é parte da vida política cotidiana numa sociedade democrática. É parte, portanto, do pleno exercício da cidadania. (OLIMPÍADA DE LP, 2010, p. 17-18).

Nessa fase do material de escrita, encontramos uma contextualização das condições de produção, recepção e circulação (BRAIT, 2002) do gênero artigo de opinião, principalmente no campo jornalístico, seja ele impresso ou em rede on-line. O primeiro destaque é que os artigos de opinião têm sua origem em questões polêmicas de nosso cotidiano, pois são as incertezas/ diferenças que levam o cidadão a se manifestar sobre determinado assunto. Ao falar dos veículos de imprensa (jornais, revistas, sites, telejornais etc.), os quais nos informam dos acontecimentos que estão em nosso entorno, tanto próximos como mais distantes, a proposta orienta sobre matérias assinadas e também sobre aquelas não identificadas (anônimas), como é o caso da notícia, por exemplo.

Nessa etapa da proposta de escrita, há um destaque para indícios que identificam a autoria ou não, definindo o papel dos articulistas que, segundo os autores da Olimpíada de LP (2010), “são profissionais ou especialistas que escrevem matérias assinadas (autorais) sobre algum assunto que está sendo discutido na mídia impressa, internet ou televisão" (p. 19). No caso específico do artigo de opinião, geralmente, o articulista é uma pessoa convidada "por uma empresa jornalística para escrever porque é reconhecido(a), tanto por ela como pelos leitores, como alguém que tem contribuição própria relevante para o debate" (p. 19).

De certa maneira, esses articulistas acabam sendo formadores de opinião, pois, ao produzir um artigo de opinião, o articulista posiciona-se diante de determinado acontecimento social, retomando o que já foi dito e apresentando novas perspectivas sobre o assunto em debate. Esse processo faz com que incorpore a fala de outros a seu dizer, na intenção de fortalecer seu ponto de vista e convencer seu leitor.

No entender dos organizadores da proposta da Olimpíada de LP, aprender a ler e escrever o gênero artigo de opinião, principalmente no meio escolar, trata-se de uma oportunidade de desenvolver a capacidade de argumentar, pois estimula a busca por elementos que sustentam sua tese. Assim, a escolha do tema deste concurso - O lugar onde vivo - justifica-se na 
busca por incentivar a participação do aluno em debates da própria comunidade, estimulando a formar opiniões sobre assuntos importantes e levando-o a apresentar possíveis soluções. É nesse sentido que aprender a produzir artigos de opinião pode ser visto como um ato social, que auxilia na formação do cidadão (DOLZ et al., 2012).

Antes de entrar nas oficinas e nas suas respectivas etapas (ou sequências didáticas), encontramos uma chamada orientando o professor para que entenda com antecedência as atividades sob uma perspectiva do conjunto, e também de cada etapa, cujo processo dará origem a um produto final: o artigo de opinião propriamente dito. Um dos textos finais produzidos deve ser selecionado para concorrer, em nível nacional, na $2^{a}$ edição da Olimpíada de LP. Além de providenciar o material necessário, é de fundamental importância que o professor entenda os objetivos e as estratégias da proposta, planejando cada passo, com base no cronograma das atividades. Para tanto, o mestre deve ler atentamente o manual de regulamento, que norteia a competição da Olimpíada e de seu funcionamento.

Nesse contexto, chegamos, enfim, à atividade de escrita de um artigo de opinião. A proposta Pontos de Vista está organizada em 15 oficinas com objetivos específicos e cada uma delas divide-se em diversas etapas (englobando de uma a quatro atividades), todas elas, direta ou indiretamente, direcionadas à produção de um artigo de opinião.

Considerando que a análise complexa de cada uma das 31 etapas das 15 oficinas seria uma reflexão muito extensa, optamos por mencionar todas, mas focar nossa análise em algumas consideradas mais pertinentes ao processo de produção escrita do gênero artigo de opinião. Com base no princípio de que argumentar é fundamental ao manuseio do artigo de opinião, a primeira oficina tem como objetivo mostrar o papel da argumentação e, para tanto, propõe sequências que possibilitam a análise de uma notícia. Na primeira etapa, o professor é orientado a dividir sua turma em grupos e a entregar a eles a coletânea de artigos dessa natureza (parte do kit) para que leiam a notícia Menino de nove anos é internado após agressão na escola. Cabe destacar que há um exercício de motivação inicial, antes da leitura do texto em foco, criando hipóteses sobre a manchete e suas possibilidades, o que tende a despertar interesse em ler a notícia e saber mais sobre o caso. 
$\mathrm{Na}$ mesma sequência, encontramos um roteiro de leitura (com sete questões) que visa a compreender e refletir sobre o acontecimento noticiado. As questões são interessantes, mas, com exceção da primeira (que incentiva a refletir sobre a importância do debate e da argumentação na prática social de resolução de problemas), todas as demais estão direcionadas ao conteúdo abordado na notícia. Como se está trabalhando o texto sob uma perspectiva de gênero textual, esperávamos encontrar questões enfocando aspectos de produção, circulação e recepção da notícia. Por exemplo: Quem teria escrito essa notícia? Por quê?? Quem seriam seus possiveis leitores? Onde ela normalmente éveiculada? Em que seção do jornal (revista, internet)? É comum encontrar notícias dessa natureza no nosso dia a dia? Por quê?... Felizmente, essa lacuna, que à primeira vista parece colocar em risco o foco central de trabalhar o texto sob sua perspectiva discursiva, enquanto prática verbal e social, percebida na primeira oficina, é sanada na segunda oficina, quando o objeto de estudo é a análise de um artigo de opinião.

$\mathrm{Na}$ segunda etapa da primeira oficina, encontramos orientações para produzir um jornal mural a ser exposto na sala de aula ou nas demais dependências da escola. Levando em conta a discussão já realizada na fase inicial, os alunos devem ser orientados (a partir de um pequeno roteiro) a produzir uma matéria assinada, que será divulgada no mural, pois, no entender dos organizadores da Olimpíada, esse material pode servir como porta-voz das diferentes opiniões existentes no ambiente escolar, no que se refere aos mais diversos assuntos. Há, ainda, instruções para que os alunos troquem entre si seus textos, assim tomando ciência das diferentes opiniões de seus colegas, o que tende a estimular o debate. A sugestão é que apenas os textos mais representativos sejam expostos, mas não existem orientações ao professor sobre esse processo seletivo. Particularmente, pensamos que todos os textos poderiam ser expostos e não somente os considerados melhores.

$\mathrm{Na}$ terceira etapa da primeira oficina, é sugerida a leitura do texto Argumentar em situações difíceis, de Philippe Breton, com o objetivo de promover um debate oral sobre o valor da argumentação na nossa convivência diária com o outro, destacando aspectos comuns e divergentes. Nesse momento, também há sugestão para que o professor ouça textos do CD- ROM (parte do kit). Na quarta etapa, o professor deve orientar seu aluno sobre o funcionamento da Olimpíada de LP, explicando que serão realizadas várias 
oficinas preparatórias para produzir um texto argumentativo, mais especificamente, um artigo de opinião. Também há orientações para que o professor anote questões importantes a cada etapa do processo de produção escrita, podendo esses dados tornarem-se cruciais em fases futuras, principalmente no caso dos textos pré-selecionados.

A partir da diferença entre as noções de argumentar e de opinar, a segunda oficina é desenvolvida em três fases, na busca de uma definição de argumentação. Inicialmente, os alunos precisam escolher um dos artigos da coletânea para ler e, a partir de um roteiro (com identificação da tese e dos argumentos usados), devem identificar onde tais textos circulam, quem os escreve, quem costuma lê-los e com qual objetivo. Feito isso, há uma atividade (com roteiro norteador) que visa a reconhecer as principais características do artigo de opinião, levando em conta sua circulação, temática (teor polêmico), autoria, produção, finalidade e recepção. Na segunda sequência, apresentamse textos que definem o ato de argumentar e propõe-se um debate para definir o que é argumentação. Finalizando essa oficina, há uma proposta para trabalhar com um jornal impresso (local). Após manuseá-lo e lê-lo, o aluno deve selecionar um artigo de opinião, trabalhando com os roteiros já vistos anteriormente.

O foco da terceira oficina é diferenciar o ato de informar e de opinar e, para isso, o aluno é orientado a fazer análise comparativa entre uma notícia e um artigo de opinião, cujos temas são internet e eleição. Na primeira etapa, propõe-se o estudo de uma charge (Por uma internet controlada, Angeli - Folha de São Paulo, 15/09/09) e de uma notícia (Senado libera internet na eleição, mas limita debate - de Fábio Zanini, Folha Online, 16/09/09), ambos textos que fazem parte da coletânea. Vale destacar que as atividades são condizentes com a perspectiva de gênero, pois contam com o apoio da definição de notícia (inclusive manchete e lead) e os exercícios levam em conta os aspectos de produção, circulação e recepção dos textos em estudo. Na segunda fase, é sugerido que o professor ouça ou projete um artigo de opinião (Internet e eleições, de Joaquim Falcão - Especial da Folha de São Paulo, 17/09/09), acompanhando sua leitura no material impresso da coletânea. Além disso, há exercícios que levam à compreensão e à interpretação dos textos, estabelecendo relações semânticas e textuais entre eles. 
Na quarta oficina, sob a rubrica Questões polêmicas, o aluno começa a desenvolver a habilidade de identificar e formular questões polêmicas e também construir bons argumentos. Tem-se como apoio definições de estratégias argumentativas e de questões polêmicas. Na segunda etapa, há orientação para realizar um debate orientado e mediado, com o objetivo de desenvolver tanto a oralidade quanto o uso de argumentos pertinentes a questões polêmicas. Na quinta oficina, a única atividade volta-se a preparar o aluno, através de roteiro norteador, a produzir individualmente um artigo de opinião. Vale enfatizar a existência de orientação para que os textos sejam lidos pelo colega, com sugestões de melhora, e somente então o autor vai reescrever cuidadosamente seu texto. Também há um roteiro de avaliação do texto, conferindo se todos os elementos estudados foram contemplados no artigo produzido.

A oficina seis sugere a leitura de vários artigos de opiniões (tanto os da coletânea como outros mais) para identificar e analisar elementos textuais e argumentativos desse gênero (sua organização, enfim, sua caracterização). Há uma proposta de estratégia de leitura orientada do tex to Corrupção cultural ou organizada?, de Renato J. Ribeiro - publicado na Folha de São Paulo, em 29 de agosto de 2009.

$\mathrm{Na}$ sequência, a oficina sete aprofunda, em duas etapas, o estudo da organização textual do artigo de opinião, abordando seu esquema argumentativo, com base no modelo do filósofo britânico Stephen Toulmin. Trata-se de uma transposição didática da teoria, aplicada ao texto de Renato J. Ribeiro, já em estudo, e não de meras definições soltas e sem sentido. E, conforme Schneuwly (2014), o processo de transformação didática, como mostram muitos estudos, transforma o saber (savoir) e o saber-fazer (savoirfaire) em um produto novo, com diferente sentido, com outra forma. Isso não significa uma simplificação, mas um processo criativo que torna o saber acessível para ser estudado na escola. Nas palavras de Schneuwly (2014, p. 15, tradução nossa), “a transposição didática é um processo construtivo profundamente cultural do qual participam múltiplos atores". ${ }^{2}$ Nessa fase, temos ainda como aporte teórico informações sobre a organização do texto

\footnotetext{
${ }^{2}$ La transposition didactique est un processus constructif profondement culturel auquel participent de multiples acteurs.
} 
dissertativo, que pode ser predominantemente expositivo ou argumentativo, dependendo da intenção do autor.

A oficina oito continua estabelecendo relação entre a notícia e o artigo de opinião, através do estudo de outros dois textos da coletânea. Para tanto, há enfoque aos aspectos de uma questão polêmica e análise da construção argumentativa usada pelo articulista e também o papel do contra-argumento nesse processo. Nesse momento, o educando deve escrever um artigo de opinião contestando um dos textos lidos e discutidos em aula.

$\mathrm{Na}$ continuidade, a oficina nove foca suas duas etapas em atividades que orientam como sustentar uma tese. Como apoio teórico, temos um quadro que define e exemplifica diferentes tipos de argumentos, bem como sua transposição em uma atividade prática de uso desses argumentos, em três situações pré-determinadas. Já as duas fases que constituem a oficina dez estão direcionadas ao estudo e uso de palavras e expressões que estabelecem relações e articulações argumentativas, o que Ducrot (2001) chama de operadores argumentativos. A metodologia dessa atividade é bem produtiva, pois trabalha a gramática através do uso, ou melhor, do sentido construído. Aqui, também há uma proposta de produção escrita do artigo de opinião.

Com foco em vozes que falam direta ou indiretamente em um artigo de opinião, a oficina onze está dividida em duas etapas. Depois de orientar sobre o que são essas vozes e como elas dialogam no texto argumentativo, a primeira etapa sugere que o aluno leia o artigo Só há notícia se for muito ruim, de Carlos Brickmann - publicado na Coluna Boas Novas, em 18 de agosto de 2009 (componente da coletânea), na tentativa de encontrar pistas que possam caracterizar esse gênero, identificando a questão polemizada e o modo como o articulista constrói sua argumentação. $\mathrm{Na}$ segunda etapa, há questões que orientam o aluno a encontrar as vozes expressas explícita e implicitamente no artigo, sejam elas do próprio articulista como de outros falantes. Há comentários, ao longo do texto em estudo que auxiliam o aluno na análise da articulação das vozes em um artigo de opinião. Nesse sentido, a oficina doze ressalta a importância de ler e pesquisar sobre o assunto a ser polemizado, relacionando seu ponto de vista com outros já manifestados socialmente. As duas etapas trazem subsídios para que o professor auxilie o estudante a pesquisar em jornais, internet, órgãos públicos etc. sobre questões polêmicas em sua comunidade e, posteriormente, socialize com o grande grupo os resultados obtidos a partir da investigação. 
A oficina treze está centrada na aprendizagem por meio da prática e propõe, nessa perspectiva, a análise e a reescritura de um artigo de opinião escrito por um dos colegas da turma, ou mesmo do texto exemplo denominado $O$ lugar onde vivo, apresentado no Caderno do Professor, caso nenhum aluno autorize o estudo de seu próprio texto. Na primeira etapa, há um roteiro norteador para ler e identificar aspectos que podem melhorar a qualidade do dizer expresso no texto lido. Dizem respeito às primeiras impressões. Somente na segunda etapa, divididos em pequenos grupos, os alunos devem reescrever o texto em questão. No caso do texto-exemplo, há um quadro anexo orientando sobre pontos importantes a serem revistos e reescritos. Por fim, na terceira etapa, há uma proposta de reescrita do texto na lousa, coletivamente.

$\mathrm{Na}$ oficina quatorze, chegamos, enfim, ao objetivo principal da proposta, ou seja, escrever individualmente um artigo de opinião. Após rememorar as orientações recebidas ao longo desse processo (fazendo uso da construção da memória didática, como explicam Sales Cordeiro e Schneuwly (2007)), é chegado o momento de colocar toda essa aprendizagem em prática. Escrito o artigo, a oficina quinze finaliza o trabalho, propondo que o aluno releia e reescreva seu texto, com base em um roteiro norteador (com perspectivas textuais, linguísticas, enunciativas e discursivas), depois o entregue ao professor e discutam de que modo o texto será socializado na escola ou fora dela. Há, no final do Caderno do Professor, uma tabela de critérios para avaliar o melhor texto a ser enviado à Comissão Organizadora da Olimpíada de LP.

No que tange aos 16 textos que constituem a Coletânea artigos de opinião dessa coleção, impressos em 10 exemplares, todos eles são de caráter polêmico e circulam no campo midiático, seja impresso ou digitalizado, via jornal, revista, internet, e englobam charge, notícia e artigos de opinião, todos de diferentes autorias. Vale destacar que as fontes são variadas, a saber: Folha de São Paulo (impressa e também on-line), Época/Agência Brasil, Jornal do Brasil, Agência Estado, Carta Capital, Folha de Londrina, Jornal Zero Hora (RS) e um texto de aluno vencedor na $1^{\text {a }}$ edição da Olimpíada de LP, o que enriquece a qualidade e a diversidade do material que compõe o kit. Todo esse material está também no CD-ROM, podendo ser ouvido e ou projetado, e é enriquecido com outros gêneros de artigo de opinião não impressos, que 
também podem ser usados como material de apoio na prática das 15 oficinas dessa coleção.

\section{Considerações Finais}

Por mais que se tenha buscado construir uma concepção discursiva do processo de produção de gêneros textuais promovido, em todo o Brasil, através das Olimpíadas de LP, a presente abordagem trata-se de uma análise parcial, pois nosso foco residiu na análise do material didático, em detrimento do processo de circulação e de recepção do programa, uma vez que não fomos até o meio escolar verificar de que modo a proposta foi realizada, nem investigamos quais efeitos ela produziu no aperfeiçoamento da capacidade de escrita do aluno. No entanto, acreditamos que essa delimitação na investigação não compromete a importância de nosso estudo, já que a qualidade do kit que compõe o programa não é garantia, mas é elemento essencial para que os objetivos da proposta de escrita sejam atingidos com sucesso.

Sob essa ótica, o ponto de interesse de nossa reflexão foi conferir se as sequências didáticas propostas nas oficinas são teoricamente coerentes com o grande objetivo de escrita, ou seja, produzir gêneros textuais, mais especificamente o gênero artigo de opinião. Isso possibilita que a prática de escrita nas aulas de língua deixe de ser um exercício mecânico de fazer redação para o professor corrigir, principalmente, fazer sua higienização lexical e gramatical e passe a ser uma ação social.

Ao analisar as 31 etapas constituintes das 15 oficinas da Coleção Ponto de $V$ ista, foi possível constatar que as atividades são pertinentes à proposta de produzir gêneros de texto, pois elas enfocam o processo de escrita nos seus diversos aspectos tanto linguístico, textual, lexical, enunciativo, pragmático como discursivo, levando em conta elementos do conteúdo, da composição e do estilo, conforme a perspectiva discursiva bakhtiniana. Enfim, as atividades organizadas em sequências didáticas procuram dar conta do processo verbal interativo que constitui a expressão escrita, considerando elementos que definem e caracterizam o gênero artigo de opinião, na medida em que exerce sua função social de tomada de posição, diante de uma questão polêmica. Há orientações sobre a importância da defesa de uma tese, com argumentos 
e contra-argumentos pertinentes ao tema em foco, bem como acerca da importância das diferentes estratégias argumentativas empregadas pelo articulista e também das diversas vozes que podem fortalecer ou enfraquecer o ponto de vista defendido no texto. Em síntese, a produção de texto é proposta de modo que alguém diz algo a outro alguém, em dada situação, sob determinada intenção, sob uma perspectiva discursiva.

Outro aspecto positivo na proposta analisada foi a visível preocupação em oportunizar diferentes momentos de escrita, pelo meio dos quais o professor pode diagnosticar aquilo que o aluno já sabe sobre o gênero artigo de opinião, fornecendo subsídios para elaborar sequências apropriadas às necessidades que ainda precisam ser sanadas, dando, assim, margem à realização dos módulos didáticos, propostos por Schneuwly e Dolz (2010). Também há ênfase na prática da releitura dos textos produzidos com roteiros norteadores para reescrevê-los, tanto de modo coletivo quanto individualmente.

À título de ilustração sobre a dimensão de abrangência do projeto da Olimpíada de LP, segundo reportagem da revista Lingua Portuguesa de dezembro de 2012, participaram, em 2010, 5.488 cidades, somando 239.453 inscrições de professores de 60.123 escolas públicas, envolvendo mais de milhões de alunos. Já em reportagem da Lingua Portuguesa publicada em janeiro de 2013, a organização da Olimpíada informou que, no ano de 2012, participaram mais de três milhões de alunos e cem mil professores, pertencentes a quarenta mil escolas públicas, de mais de cinco mil municípios brasileiros. Conforme dados desse periódico, enquanto professores e alunos vencedores da terceira edição da Olimpíada de LP, finalizada em dezembro de 2012, receberam medalhas de ouro e notebooks, suas respectivas escolas receberiam laboratórios de informática, com dez computadores, impressora, projetor e telão, além de livros para suas bibliotecas.

É sabido que o programa ainda não conseguiu atingir seu grande propósito nacional, mas, certamente, estamos no caminho e é sempre bom poder visualizar possibilidades de melhora na qualidade de nossa educação, em especial no ensino de língua e de produção escrita. Após análise do material que constitui a proposta da Olimpíada de LP, mais especificamente da coleção voltada aos $2^{\circ}$ e $3^{\circ}$ anos do EM, podemos dizer que o material está bem organizado e está teoricamente bem fundamentado, o que torna a 
proposta coerente com o propósito de aperfeiçoar a capacidade de expressão escrita do aluno, por meio de gêneros textuais. Na sequência de nosso estudo sobre esse tema, estamos projetando realizar pesquisas voltadas tanto à observação da prática docente quanto à análise dos textos finais produzidos pelos alunos, na tentativa de investigar os efeitos que a proposta de escrita de gêneros textuais da Olimpíada vem produzindo na capacidade de escrita de nosso aluno.

\section{Referências}

BAKHTIN, M. Estética da criação verbal. São Paulo: Martins Fontes, 1992.

BRAIT, B. PCNs, gêneros e ensino de língua: faces discursivas da textualidade. In: ROJO, R. (Org.). A prática de linguagem na sala de aula. Praticando os PCNs. São Paulo: Mercado Aberto, 2002.

BRONCKART, J-P. O agir nos discursos: das concepções teóricas às concepções dos trabalhadores. São Paulo: Mercado de Letras, 2008.

BRONCKART, J-P. Atividade de linguagem, textos e discursos. Por um interacionismo sociodiscursivo. São Paulo: EDUC, 2012.

DOLZ, J; ROSAT, M-C; SCHNEUWLY, B. Élaboration et évaluation de deux séquences didactiques relatives de trois types de textes. Le français aujourd'bui, Paris, n. 93, p. 37-47, 1991.

DOLZ, J.; NOVERRAZ, M.; SCHNEUWLY, B. Sequências didáticas para o oral e a escrita: apresentação de um procedimento. In: SCHNEUWLY, B.; DOLZ, J. et al. Gêneros orais e escritos na escola. São Paulo: Mercado de Letras, 2010. p. 81-108.

DOLZ, J.; GAGNON, R.; VUILLET, Y. Production écrite et difficultés d'apprentissage. Genève: Université de Genève, 2011.

DOLZ, J. et al. Dédoublement du genre et opérations de fictionalisation: Faire "comme si c'était vrai", ou divers visages de l'alteration didactique. Éducation \& Didactique, v. 6, n. 2, p. 69-102, 2012. 
DUCROT, O. Critères argumentatifs et analyse lexicale. Langages, n. 142, p. 22-40, juin 2001.

FUHRMANN. L. O prêmio é o de menos. Lingua Portuguesa, São Paulo, a. 8, n.88, p. 16-19, 2013.

GUIMARÃES, A. M. A. M.; MACHADO A. R.; COUTINHO, A. (Org.). O Interacionismo Sociodiscursivo: questões epistemológicas e metodológicas. São Paulo: Mercado de Letras, 2007.

A OLIMPÍADA da escrita criativa. Lingua Portuguesa, São Paulo, a. 8, n. 86 , p. $51,2012$.

MACHADO, A. R. A perspectiva interacionista sociodiscursiva de Bronckart. In: MEURER, J. L. et al. Gêneros: teorias, métodos, debates. São Paulo: Parábola, 2005.

MARCUSCHI, L. A. Gêneros textuais: definição e funcionalidade. In: DIONÍSIO, A. P.; MACHADO, A. B.; BEZERRA, M. A. (Org.). Gêneros textuais \& ensino. Rio de Janeiro: Lucerna, 2002.

MARCUSCHI, L. A. Produção textual, análise de gêneros e compreensão.

São Paulo: Parábola, 2008.

OLIMPÍADA DE LÍNGUA PORTUGUESA - Escrevendo o Futuro. Pontos de Vista. Caderno do Professor. São Paulo: Cenpec, 2010.

OLIMPÍADA DE LÍNGUA PORTUGUESA - Escrevendo o Futuro. Coletânea artigo de opinião. São Paulo: Cenpec, 2010.

OLIMPÍADA DE LÍNGUA PORTUGUESA - Escrevendo o Futuro. Disponível em: <www.escrevendoofuturo.org.br>. Acesso em: 25 fev. 2012.

PEREIRA, C. C. et al. Gêneros textuais e modos de organização do discurso: uma proposta para a sala de aula. In: PAULIUKONIS, M. A. L.; SANTOS, L. W. (Org.). Estratégias de Leitura - texto e ensino. Rio de Janeiro: Lucerna, 2006. 
SALES CORDEIRO, G. ; SCHNEUWLY, B. Les constructions de l'objet enseigné et les organisateurs du travail enseignant. Recherche et Formation, n. 96, p. 67-79, 2007.

SCHNEUWLY, B. Qu'est-ce qu'apprendre/enseigner à lire et à écrire aujourd'hui?. Recherches, n. 20, p. 51-60, 1994.

SCHNEUWLY, B. Didactique: construction d'un champ disciplinaire. Éducation et Didactique, v. 8, n. 1, p. 13-22, 2014.

SCHNEUWLY, B. ; DOLZ, J. Des objets enseignés en classe de français. Le travail de l'enseignant sur la rédaction de textes argumentatifs et sur la subordonnée relative. Presses Universitaires de Rennes, 2009.

SCHNEUWLY, B. ; DOLZ, J. Gêneros orais e escritos na escola. São Paulo: Mercado de Letras, 2010.

WIITKE, C. I. Ensino de lingua materna: PCNs, gramática e discurso. Santa Cruz do Sul: EDUNISC, 2007.

WIITKE, C. I. Ensino de língua e formação docente. Reflexão teórica e diálogo com professores. Saarbrücken: Verlang; Novas Edições Acadêmicas, 2015.

WITTKKE, C. I.; DOLZ, J. Ensino de língua, formação docente e pesquisa: um diálogo com Joaquim Dolz. Fórum Linguístico, v. 12, n. 4, p. 986-997, out./dez. 2015.

Recebido em: 01/07/2015

Aceito: $22 / 12 / 2015$ 